\title{
Response of Different Levels of Nitrogen and Phosphorus on Tthe Growth and Yield of French Bean
}

\author{
R. Sen ${ }^{\mathrm{a}}$, M. A. Rahman ${ }^{\mathrm{b}}$, A. K. M. S. Hoque ${ }^{\mathrm{a}}$, S. Zaman ${ }^{\mathrm{b}}$, and S. Noor ${ }^{\mathrm{a}}$ \\ ${ }^{a}$ Soil Science Division, Bangladesh Agricultural Research Institute, Joydebpur and ${ }^{b}$ Regional \\ Agricultural Research Station, BARI, Jamalpur
}

\begin{abstract}
A field experiment on French bean was conducted in Old Brahmaputra Floodplain Soil of Jamalpur and Grey Terrace Soil of Joydebpur during 2005-2006 to find out the optimum rates of N and P for yield maximization. Four levels of nitrogen (0, 100,150 and $\left.200 \mathrm{~kg} \mathrm{ha}^{-1}\right)$ and 3 levels of phosphorus (0, 40 and $60 \mathrm{~kg} \mathrm{ha}^{-1}$ ) were used in the experiment. Potassium (K) $80 \mathrm{~kg}$, sulphur (S) $10 \mathrm{~kg}$ and $5 \mathrm{t} \mathrm{cowdung} \mathrm{ha}{ }^{-1}$ were applied as a basal dose. The experiment was laid out in a randomized complete block design with 12 treatments replicated 4 times. Nitrogen and phosphorus alone significantly influenced the pod yield of French bean. Among the $\mathrm{N}$ levels, the highest pod yield (13.33 $\mathrm{t}$ $\mathrm{ha}^{-1}$ at Jamalpur and $14.68 \mathrm{t} \mathrm{ha}^{-1}$ at Joydebpur) were obtained with $150 \mathrm{~kg} \mathrm{~N} \mathrm{ha}^{-1}$. Among the P levels, the highest pod yield (12.35 $\mathrm{t}$ ha ${ }^{-1}$ at Jamalpur and $13.69 \mathrm{t} \mathrm{ha}^{-1}$ at Joydebpur) were obtained with $60 \mathrm{~kg} \mathrm{P} \mathrm{ha}^{-1}$. Interaction effect was not significant. However, highest pod yield (13.60 t ha ${ }^{-1}$ at Jamalpur and $15.05 \mathrm{t} \mathrm{ha}^{-1}$ at Joydebpur) was obtained from $150 \mathrm{~kg} \mathrm{~N}$ plus $60 \mathrm{~kg} \mathrm{P}^{-1}$. Economic analysis showed that $150 \mathrm{~kg} N$ plus $40 \mathrm{~kg} \mathrm{P} \mathrm{ha}^{-1}$ gave the highest gross margin of Tk. 1,66,684/ha.
\end{abstract}

Key words : French bean; Nitrogen and phosphorus fertilization; Pod yield

\section{Introduction}

French bean (Phaseolus vulgaris) is one of the most important leguminous vegetables in the world. It is an export oriented vegetable which is rich in protein, calcium, iron and vitamins (Haque et al, ). It is used as vegetables when pods are immature and tender. French bean is an important under utilized vegetable in Bangladesh (Rahman et al., 2002). French bean can easily be grown in field as well as in homestead garden if the soil is managed properly. Srinivas and Naik observed that the pod yield of French bean increased with increasing rate of $\mathrm{N}$ application and they obtained 13.2 t ha ${ }^{-1}$ pod by using $160 \mathrm{~kg} \mathrm{~N} \mathrm{ha}^{-1}$ (Srinivas and Naik, 1988). Guu et al. (1997) recorded $17.2 \mathrm{t} \mathrm{ha}^{-1}$ pod yield with fertilizer and manure application. Research on fertilizer management for French bean in Bangladesh is in preliminary stage. The present research work was, therefore, undertaken to find out the response of French bean to different rates of nitrogen and phosphorus.

\section{Materials and Method}

The experiment was conducted at BARI Regional Station, Jamalpur and BARI central farm, Joydebpur during 20052006 to find out the optimum rate of nitrogen and phosphorus for French bean. Before starting the experiment, soil samples was collected from the field and analyzed in the laboratory following standard methods. The nutrient status of the initial soil has been presented in Table I.

Organic matter content of the soil were poor. The soils were acidic in nature. Phosphorus, potassium, sulphur, boron and zinc status of the soil were found to be either at par or below the critical level. Based on soil test values the different treatment combinations were formulated as follows :

\section{Table I. Nutrient status of experimental soil prior to fertilization}

\begin{tabular}{l|c|c|c|c|c|c|c|c|c|c|c|c|c|c|}
\hline Location & Textural class & $\mathrm{pH}$ & $\mathrm{OM} \%$ & $\mathrm{Ca}$ & $\mathrm{Mg}$ & $\mathrm{K}$ & Total N \% & $\mathrm{P}$ & $\mathrm{S}$ & $\mathrm{B}$ & $\mathrm{Fe}$ & $\mathrm{Zn}$ \\
\hline & & & & \multicolumn{3}{|c|}{ meq/100g } & & \multicolumn{4}{|c}{$\mu \mathrm{g} / \mathrm{g}$} \\
\hline Jamalpur & Clay loam & 5.8 & 0.95 & 4.2 & 1.7 & 0.13 & 0.05 & 14 & 12 & 0.24 & 120 & 1.3 \\
Joydebpur & Silty loam & 6.4 & 1.60 & 6.4 & 2.9 & 0.18 & 0.07 & 13 & 16 & 0.30 & 161 & 2.0 \\
Critical level & - & - & - & 2.0 & 0.8 & 0.20 & - & 14 & 14 & 0.20 & 10 & 2.0 \\
\hline
\end{tabular}

* Corresponding author: E-mail: : 
Treatment combinations of nitrogen and phosphorus fertilizer :

There are twelve treatment combinations comprising 4 levels of $\mathrm{N}\left(0,100,150\right.$ and $\left.200 \mathrm{~kg} \mathrm{ha}^{-1}\right)$ and 3 levels of $\mathrm{P}(0$, 40 and $60 \mathrm{~kg} \mathrm{ha}^{-1}$ ). The treatments were arranged in factori

\begin{tabular}{llll}
\hline $\mathrm{T}_{1}=$ & $\mathrm{N}_{0} \mathrm{P}_{0} \mathrm{~kg} \mathrm{ha}^{-1}$ & $\mathrm{~T}_{7}=$ & $\mathrm{N}_{150} \mathrm{P}_{40} \mathrm{~kg} \mathrm{ha}^{-1}$ \\
$\mathrm{~T}_{2}=$ & $\mathrm{N}_{100} \mathrm{P}_{0} \mathrm{~kg} \mathrm{ha}^{-1}$ & $\mathrm{~T}_{8}=$ & $\mathrm{N}_{200} \mathrm{P}_{40} \mathrm{~kg} \mathrm{ha}^{-1}$ \\
$\mathrm{~T}_{3}=$ & $\mathrm{N}_{150} \mathrm{P}_{0} \mathrm{~kg} \mathrm{ha}^{-1}$ & $\mathrm{~T}_{9}=$ & $\mathrm{N}_{0} \mathrm{P}_{60} \mathrm{~kg} \mathrm{ha}^{-1}$ \\
$\mathrm{~T}_{4}=$ & $\mathrm{N}_{200} \mathrm{P}_{0} \mathrm{~kg} \mathrm{ha}^{-1}$ & $\mathrm{~T}_{10}=$ & $\mathrm{N}_{100} \mathrm{P}_{60} \mathrm{~kg} \mathrm{ha}^{-1}$ \\
$\mathrm{~T}_{5}=$ & $\mathrm{N}_{0} \mathrm{P}_{40} \mathrm{~kg} \mathrm{ha}^{-1}$ & $\mathrm{~T}_{11}=$ & $\mathrm{N}_{150} \mathrm{P}_{60} \mathrm{~kg} \mathrm{ha}^{-1}$ \\
$\mathrm{~T}_{6}=$ & $\mathrm{N}_{100} \mathrm{P}_{40} \mathrm{~kg} \mathrm{ha}^{-1}$ & $\mathrm{~T}_{12}=$ & $\mathrm{N}_{200} \mathrm{P}_{60} \mathrm{~kg} \mathrm{ha}^{-1}$ \\
\hline
\end{tabular}

al RCB design with 4 replications. A blanket dose of $80 \mathrm{~kg}$ $\mathrm{K}, 10 \mathrm{~kg} \mathrm{~S}$ and $5 \mathrm{t}$ cowdung ha ${ }^{-1}$ was applied in the experiment. The sources of N, P, K and S were urea, TSP, MP and gypsum, respectively. The unit plot size was $3.0 \mathrm{~m} \times 2.4 \mathrm{~m}$. The whole amount of $\mathrm{P}, \mathrm{K}, \mathrm{S}$, cowdung and $1 / 2$ of $\mathrm{N}$ were applied at final land preparation and the remaining $1 / 2$ of $\mathrm{N}$ was top dressed 25 days after sowing. The tested variety was BARI French bean ${ }^{-1}$. The seeds of French bean were sown on late November in both the years at both locations with a spacing of $25 \mathrm{~cm} \times 15 \mathrm{~cm}$. Intercultural operations like weeding, irrigation and pest control measures were done as and when required. Data on yield components were collected. The green pods were harvested 4 times in February at both locations. The collected data were analyzed statistically by computer following IRRISTAT package (Perrin et al., 1979).

\section{Results and Discussion}

\section{Effect of nitrogen on the growth and yield of French bean}

French bean responded significantly to different levels of nitrogen (Table II). Yield and yield components of French bean increases with the increase of nitrogen upto $150 \mathrm{~kg} \mathrm{~N}$ $\mathrm{ha}^{-1}$ and decrease thereafter. The highest number of pods/plant (25.90 at Jamalpur and 27.90 at Joydebpur), pod length (14.68 cm at Jamalpur and $14.98 \mathrm{~cm}$ at Joydebpur) and pod circumference $(1.15 \mathrm{~cm}$ at Jamalpur and $1.17 \mathrm{~cm}$ at Joydebpur) were recorded in the treatment that received 150 $\mathrm{kg} \mathrm{N}$ ha $^{-1}$. Plant height was found highest $(39.68 \mathrm{~cm}$ at Jamalpur and $40.26 \mathrm{~cm}$ at Joydebpur) in the same treatment. The highest significant pod yield (13.33 $\mathrm{t} \mathrm{ha}^{-1}$ at Jamalpur and $14.68 \mathrm{t} \mathrm{h}^{-1} 1$ at Joydebpur) was obtained with $150 \mathrm{~kg} \mathrm{~N}$ ha $^{-1}$ which was statically similar with N@ 200 kg/ha treated yield (12.99 $\mathrm{t} \mathrm{ha}^{-1}$ at Jamalpur and $14.55 \mathrm{t} \mathrm{ha}^{-1}$ at Joydebpur). The lowest pod yield (7.03 $\mathrm{t} \mathrm{ha}^{-1}$ at Jamalpur and $8.46 \mathrm{t} \mathrm{ha}^{-1}$ at Joydebpur) was obtained from $\mathrm{N}$-control treatment. Higher pod circumference and length, and pods/plant might have contributed to the higher yield of French bean. The result is in agreement with that of Hoque et al and Singh (2000). Hoque et al. and Singh (2000) obtained highest pod yield (13.5 and 14.9 t/ha, respectively) with the application of $150 \mathrm{~kg}$ Nitrogen. Pod yield increased significantly with each successive increment in N up to 120 kg/ha were reported (Baboo et a1., 1998).

\section{Effect of phosphorus on the growth and yield of French bean}

Different levels of phosphorus significantly influenced the yield and yield components of French bean (Table III). The highest number of pods/plant (24.18 at Jamalpur and 24.83 at Joydebpur), pod length (14.29 $\mathrm{cm}$ at Jamalpur and 14.62 $\mathrm{cm}$ at Joydebpur) and pod circumference $(1.12 \mathrm{~cm}$ at Jamalpur and $1.17 \mathrm{~cm}$ at Joydebpur) were recorded in the treatment that received $60 \mathrm{~kg} \mathrm{P} \mathrm{ha}^{-1}$. Plant height was found highest (38.17 $\mathrm{cm}$ at Jamalpur and $38.69 \mathrm{~cm}$ at Joydebpur) in the same treatment. The highest significant pod yield (12.35 $\mathrm{t} \mathrm{ha}^{-1}$ at Jamalpur and $13.69 \mathrm{t} \mathrm{ha}^{-1}$ at Joydebpur) was obtained with 60 kg P ha-1 which was followed by P @ 40 $\mathrm{kg} / \mathrm{ha}$ treated yield (11.54 $\mathrm{t} \mathrm{ha}^{-1}$ at Jamalpur and $12.80 \mathrm{t} \mathrm{ha}^{-1}$ at Joydebpur). The lowest pod yield (10.12 $\mathrm{t} \mathrm{ha}^{-1}$ at Jamalpur and $11.53 \mathrm{t} \mathrm{ha}^{-1}$ at Joydebpur) was obtained from P-control treatment. It is revealed that pod yield increased with

Table II. Effect of different levels of nitrogen on the growth and yield of French bean during 2005-06

\begin{tabular}{c|c|c|c|c|c|c|c|c|c|c}
\hline \multirow{2}{*}{$\begin{array}{c}\text { Treat- } \\
\text { ment }\end{array}$} & \multicolumn{2}{|c|}{ Plant height $(\mathrm{cm})$} & \multicolumn{2}{|c|}{ Pod length $(\mathrm{cm})$} & \multicolumn{2}{c|}{$\begin{array}{c}\text { Pod circumference } \\
(\mathrm{cm})\end{array}$} & \multicolumn{2}{c|}{ Pods/plant (no.) } & \multicolumn{2}{c}{ Pod yield (t/ha) } \\
\cline { 2 - 11 } & Jamalpur & Joydebpur & Jamalpur & Joydebpur & Jamalpur & Joydebpur & Jamalpur & Joydebpur & Jamalpur & Joydebpur \\
\hline $\mathrm{N}_{0}$ & $34.19 \mathrm{~b}$ & $35.00 \mathrm{~b}$ & $12.87 \mathrm{ab}$ & $13.10 \mathrm{~b}$ & 1.08 & 1.13 & $18.47 \mathrm{c}$ & $19.53 \mathrm{~d}$ & $7.03 \mathrm{c}$ & $8.46 \mathrm{c}$ \\
$\mathrm{N}_{100}$ & $35.56 \mathrm{~b}$ & $35.98 \mathrm{~b}$ & $13.78 \mathrm{a}$ & $13.95 \mathrm{~b}$ & 1.10 & 1.17 & $21.73 \mathrm{~b}$ & $21.70 \mathrm{c}$ & $12.01 \mathrm{~b}$ & $13.00 \mathrm{~b}$ \\
$\mathrm{~N}_{150}$ & $39.68 \mathrm{a}$ & $40.26 \mathrm{a}$ & $14.68 \mathrm{a}$ & $14.98 \mathrm{a}$ & 1.15 & 1.17 & $25.90 \mathrm{a}$ & $27.90 \mathrm{a}$ & $13.33 \mathrm{a}$ & $14.68 \mathrm{a}$ \\
$\mathrm{N}_{200}$ & $39.45 \mathrm{a}$ & $39.61 \mathrm{a}$ & $14.43 \mathrm{a}$ & $14.72 \mathrm{a}$ & 1.12 & 1.17 & $25.20 \mathrm{a}$ & $25.00 \mathrm{~b}$ & $12.99 \mathrm{ab}$ & $14.55 \mathrm{a}$ \\
\hline $\mathrm{CV}(\%)$ & 8.1 & 8.0 & 8.7 & 8.5 & 7.6 & 7.5 & 9.8 & 9.6 & 10.4 & 9.3 \\
\hline
\end{tabular}


Table III. Effect of different levels of phosphorus on the growth and yield of French bean during 2005-06

\begin{tabular}{c|c|c|c|c|c|c|c|c|c|c}
\hline \multirow{2}{*}{$\begin{array}{c}\text { Treat- } \\
\text { ment }\end{array}$} & \multicolumn{2}{|c|}{ Plant height $(\mathrm{cm})$} & \multicolumn{2}{c|}{ Pod length $(\mathrm{cm})$} & \multicolumn{2}{c|}{$\begin{array}{c}\text { Pod circumference } \\
(\mathrm{cm})\end{array}$} & \multicolumn{2}{c|}{ Pods/plant (no.) } & \multicolumn{2}{c}{ Pod yield (t/ha) } \\
\cline { 2 - 11 } & Jamalpur & Joydebpur & Jamalpur & Joydebpur & Jamalpur & Joydebpur & Jamalpur & Joydebpur & Jamalpur & Joydebpur \\
\hline $\mathrm{P}_{0}$ & 36.24 & 36.84 & $13.48 \mathrm{c}$ & $13.71 \mathrm{c}$ & 1.11 & 1.14 & $21.78 \mathrm{c}$ & $22.15 \mathrm{c}$ & $10.12 \mathrm{c}$ & $11.53 \mathrm{c}$ \\
$\mathrm{P}_{40}$ & 37.25 & 37.60 & $14.05 \mathrm{~b}$ & $14.25 \mathrm{~b}$ & 1.12 & 1.17 & $22.53 \mathrm{~b}$ & $23.63 \mathrm{~b}$ & $11.54 \mathrm{~b}$ & $12.80 \mathrm{~b}$ \\
$\mathrm{P}_{60}$ & 38.17 & 38.69 & $14.29 \mathrm{a}$ & $14.62 \mathrm{a}$ & 1.12 & 1.17 & $24.18 \mathrm{a}$ & $24.83 \mathrm{a}$ & $12.35 \mathrm{a}$ & $13.69 \mathrm{a}$ \\
\hline $\mathrm{CV}(\%)$ & 8.1 & 8.0 & 8.7 & 8.5 & 7.6 & 7.5 & 9.8 & 9.6 & 10.4 & 9.3 \\
\hline
\end{tabular}

increasing rate of phosphorus. French bean responds to the application of phosphorus more than to other nutrient (Hagg et al., 1967) and production increases proportionately with the increase in the level of phosphorus fertilizer (Miranda and Lobato 1978). Increasing level of Phosphorus increase the pod yield of French bean were reported by Roy and Parthasarathy (Roy and Parthosarathy 1999). French been develop poorly when grown in P-deficient soil and its low level leads to low bean productivity (Kanwar 1982).

\section{Interaction effect on pod yield and yield components of} French bean

The interaction effect of $\mathrm{N}$ and $\mathrm{P}$ on pod yield and yield components of French bean was found insignificant (Table IV). However, highest pod yield (13.60 $\mathrm{t} \mathrm{ha}^{-1}$ at Jamalpur and $15.05 \mathrm{t} \mathrm{ha}^{-1}$ at Joydebpur) was obtained from $\mathrm{N}_{150} \mathrm{P}_{60}$ treatment. The lowest pod yield (5.92 $\mathrm{t} \mathrm{ha}^{-1}$ at Jamalpur and 6.92 t ha ${ }^{-1}$ at Joydebpur) was obtained from $\mathrm{N}_{0} \mathrm{P}_{0}$ treatment. Higher rates of $\mathrm{N}$ and $\mathrm{P}$ application produced higher number of pods/plant, higher pod length and circumference and as well as higher yield of pods. Nitrogen increases the plant growth and phosphorus enhances nodulation of French bean (Roy and Parthosarathy 1999). Similar findings were also reported by Baboo et al. (1998) and Singh (2000).

\section{Economic analysis}

In order to identify a suitable treatment combination, economic evaluation of different treatment combination was done through partial budgeting.

Economic analysis presented in Table $\mathrm{V}$ revealed that highest gross margin of Tk. 1,66,684/ha was obtained from the treatment $\mathrm{T}_{7}\left(\mathrm{~N}_{150} \mathrm{P}_{40} \mathrm{~kg} / \mathrm{ha}\right)$ with a variable cost $\mathrm{Tk}$. 4,556/ha. Lowest gross margin of Tk. 77,040/ha was obtained from control $\left(\mathrm{N}_{0} \mathrm{P}_{0}\right)$ treatment. Thirumalai and Khalak (1993) also reported increasing gross margin with rising $\mathrm{N}$ and $\mathrm{P}$. The rate of net returns however decreased beyond $150 \mathrm{~kg} \mathrm{~N} / \mathrm{ha}$.

\section{Table IV. Effect of different levels of phosphorus on the growth and yield of French bean during 2005-06}

\begin{tabular}{c|c|c|c|c|c|c|c|c|c|c}
\hline $\begin{array}{c}\text { Treat- } \\
\text { ment }\end{array}$ & \multicolumn{2}{|c|}{ Plant height $(\mathrm{cm})$} & \multicolumn{2}{c|}{ Pod length $(\mathrm{cm})$} & \multicolumn{2}{c|}{$\begin{array}{c}\text { Pod circumference } \\
(\mathrm{cm})\end{array}$} & \multicolumn{2}{c|}{ Pods/plant (no.) } & \multicolumn{2}{c}{ Pod yield (t/ha) } \\
\cline { 2 - 12 } & Jamalpur & Joydebpur & Jamalpur & Joydebpur & Jamalpur & Joydebpur & Jamalpur & Joydebpur & Jamalpur & Joydebpur \\
\hline $\mathrm{T}_{1}=\mathrm{N}_{0} \mathrm{P}_{0}$ & 33.56 & 34.87 & 11.65 & 11.90 & 1.07 & 1.10 & 17.20 & 18.90 & 5.92 & 6.92 \\
$\mathrm{~T}_{2}=\mathrm{N}_{100} \mathrm{P}_{0}$ & 33.93 & 34.21 & 13.61 & 13.72 & 1.10 & 1.14 & 20.30 & 20.40 & 9.86 & 11.24 \\
$\mathrm{~T}_{3}=\mathrm{N}_{150} \mathrm{P}_{0}$ & 38.92 & 39.35 & 14.56 & 14.86 & 1.16 & 1.17 & 25.00 & 26.10 & 12.78 & 14.05 \\
$\mathrm{~T}_{4}=\mathrm{N}_{200} \mathrm{P}_{0}$ & 38.55 & 38.95 & 14.10 & 14.35 & 1.11 & 1.16 & 24.60 & 23.20 & 11.93 & 13.90 \\
$\mathrm{~T}_{5}=\mathrm{N}_{0} \mathrm{P}_{40}$ & 34.11 & 34.89 & 13.46 & 13.67 & 1.08 & 1.13 & 18.80 & 19.80 & 6.29 & 8.36 \\
$\mathrm{~T}_{6}=\mathrm{N}_{100} \mathrm{P}_{40}$ & 36.11 & 36.32 & 13.73 & 14.00 & 1.10 & 1.16 & 22.40 & 22.20 & 12.79 & 13.11 \\
$\mathrm{~T}_{7}=\mathrm{N}_{150} \mathrm{P}_{40}$ & 39.22 & 39.76 & 14.61 & 14.61 & 1.18 & 1.20 & 24.80 & 28.10 & 13.60 & 14.94 \\
$\mathrm{~T}_{8}=\mathrm{N}_{200} \mathrm{P}_{40}$ & 39.56 & 39.44 & 14.41 & 14.70 & 1.12 & 1.18 & 24.10 & 24.40 & 13.49 & 14.78 \\
$\mathrm{~T}_{9}=\mathrm{N}_{0} \mathrm{P}_{60}$ & 34.89 & 35.23 & 13.49 & 13.74 & 1.08 & 1.15 & 19.40 & 19.90 & 8.88 & 10.09 \\
$\mathrm{~T}_{10}=\mathrm{N}_{100} \mathrm{P}_{60}$ & 36.66 & 37.40 & 14.00 & 14.14 & 1.11 & 1.20 & 22.50 & 22.50 & 13.37 & 14.64 \\
$\mathrm{~T}_{11}=\mathrm{N}_{150} \mathrm{P}_{60}$ & 40.89 & 41.68 & 14.86 & 15.47 & 1.12 & 1.15 & 27.90 & 29.50 & 13.60 & 15.05 \\
$\mathrm{~T}_{12}=\mathrm{N}_{200} \mathrm{P}_{60}$ & 40.22 & 40.45 & 14.79 & 15.12 & 1.12 & 1.18 & 26.90 & 27.40 & 13.54 & 14.98 \\
\hline $\mathrm{CV}(\%)$ & 8.1 & 8.0 & 8.7 & 8.5 & 7.6 & 7.5 & 9.8 & 9.6 & 10.4 & 9.3 \\
\hline
\end{tabular}


Table V. Partial budget analysis for different nitrogen and phosphorus response data of French bean (average of 2 locations)

\begin{tabular}{l|c|c|c|c|c|c}
\hline \multicolumn{1}{c|}{ Treatment } & $\begin{array}{c}\text { Nitrogen cost } \\
\text { (Tk./ha) }\end{array}$ & $\begin{array}{c}\text { Phosphorus cost } \\
\text { (Tk./ha) }\end{array}$ & $\begin{array}{c}\text { Total variable } \\
\text { cost (Tk./ha) }\end{array}$ & $\begin{array}{c}\text { Mean pod } \\
\text { yield (t/ha) }\end{array}$ & $\begin{array}{c}\text { Gross } \\
\text { return (Tk./ha) }\end{array}$ & $\begin{array}{c}\text { Gross } \\
\text { margin(Tk./ha) }\end{array}$ \\
\hline $\mathrm{T}_{1}=\mathrm{N}_{0} \mathrm{P}_{0}$ & 0 & 0 & 0 & 6.42 & 77,040 & 77,040 \\
$\mathrm{~T}_{2}=\mathrm{N}_{100} \mathrm{P}_{0}$ & 1,304 & 0 & 1,304 & 10.55 & $1,26,600$ & $1,25,296$ \\
$\mathrm{~T}_{3}=\mathrm{N}_{150} \mathrm{P}_{0}$ & 1,956 & 0 & 1,956 & 13.42 & $1,61,040$ & $1,59,084$ \\
$\mathrm{~T}_{4}=\mathrm{N}_{200} \mathrm{P}_{0}$ & 2,608 & 0 & 2,608 & 12.92 & $1,55,040$ & $1,52,432$ \\
$\mathrm{~T}_{5}=\mathrm{N}_{0} \mathrm{P}_{40}$ & 0 & 2,600 & 2,600 & 7.33 & 87,960 & 85,360 \\
$\mathrm{~T}_{6}=\mathrm{N}_{100} \mathrm{P}_{40}$ & 1,304 & 2,600 & 3,904 & 12.95 & $1,55,400$ & $1,51,496$ \\
$\mathrm{~T}_{7}=\mathrm{N}_{150} \mathrm{P}_{40}$ & 1,956 & 2,600 & 4,556 & 14.27 & $1,71,240$ & $1,66,684$ \\
$\mathrm{~T}_{8}=\mathrm{N}_{200} \mathrm{P}_{40}$ & 2,608 & 2,600 & 5,208 & 14.14 & $1,69,680$ & $1,64,472$ \\
$\mathrm{~T}_{9}=\mathrm{N}_{0} \mathrm{P}_{60}$ & 0 & 3,900 & 3,900 & 9.45 & $1,13,400$ & $1,09,500$ \\
$\mathrm{~T}_{11}=\mathrm{N}_{100} \mathrm{P}_{60}$ & 1,304 & 3,900 & 5,204 & 14.01 & $1,68,120$ & $1,62,916$ \\
$\mathrm{~T}_{11}=\mathrm{N}_{150} \mathrm{P}_{60}$ & 1,956 & 3,900 & 5,856 & 14.35 & $1,72,200$ & $1,66,344$ \\
$\mathrm{~T}_{12}=\mathrm{N}_{200} \mathrm{P}_{60}$ & 2,608 & 3,900 & 6,508 & 14.26 & $1,71,120$ & $1,64,612$ \\
\hline
\end{tabular}

Price : 1 kg N = Tk. 13.04; 1 kg P = Tk. 65; 1 kg French bean $=$ Tk. 12

\section{Conclusion}

From the above field experiment, it may be concluded that $150 \mathrm{~kg}$ nitrogen, $40 \mathrm{~kg}$ phosphorus along with a basal dose of $80 \mathrm{~kg}$ potassium, $10 \mathrm{~kg}$ sulphur and 5 t cowdung ha- 1 are found economic for optimum yield of French bean in Old Brahmaputra Floodplain Soil of Jamalpur and Grey Terrace Soil of Joydebpur.

\section{References}

Baboo R., Rana N. S. and Pantola P. (1988) Response of French bean to nitrogen and phosphorus. Ann. Agric. Res. 19 (1): 81-82.

De Miranda L. N. and Lobato E. (1978) Tolerancia de versiedade de foigaoe de trigo ao aluminio e a baixa disponibilidade de fosforo no solo. Rev. Bras. Cience Solo. 2: 44-50.

Guu J. W., Yang T. C. and Fong T. Y. (1995) Effects of organic manure on the growth and yield of common bean at fall season bulletin of Taichung. District Agricultural Improvement Station. 49: 41-48 (Cited from Horticultural Abstracts, CBA.1997. 67: 4).

Hagg H. P., Malavolta E. Garganitini H. and Blanco H. G. (1967) Absorcao de nutrientes pela culture do fei joeiro. Bragnita. 26: 381-391.

Hoque A. K. M. S., Shahiduzzaman M. and Farid A. T. M. Integrated nutrient management for French bean amaranth cropping pattern in homestead. Research Report 2001-2002, Soil Sci. Div. BARI, Joydebpur, Gazipur.
Kanwar J. S. (1982) Phosphorus management of Indian soils: Problems and prospects. Fertilizer News. 27(2) : 43-45.

Perrin R. K., Winkelam D. L., Moseardi E. R. and Anderson J. R. (1979) Farm agronomic data to farmer's recommendations. CIMMYT Mexico Proj. Information Bulletin 27: 63.

Rahman M. O., Rabbani M. G., Nasiruddin K. M., Yesmin R. and Rahman M. M. (2002) Effect of different levels of nitrogen and plant spacing on the growth and yield of French bean. Progress. Agric. 13 (1\&2): 35-37.

Roy N. R. and Parthosarathy V. A. (1999) Note on phosphorus requirement of French bean varieties planted at different dates. Indian J. Hort. 56 (4): 317-320.

Singh R. V. (2000) Response of french bean to plant spacing, and nitrogen and phosphorus fertilization. Indian $J$. Hort. 57 (4): 338-341.

Srinivas K and Naik L. B. (1988) Response of vegetable French bean (Phaseolus vulgaris) to nitrogen and phosphorus fertilization. Indian J. Agril. Sci. 58(9):707-708.

Thirumalai M. and Khalak A. (1993) Fertilizer application economics in French bean. Cur. Res., Univ. Agric. Sci. (Bangalore). 22 : 67-69.

Received : October 12, 2008;

Accepted : September 15, 2009 